ROCZNIKI HUMANISTYCZNE

Volume 66, issue $1-2018$

SELECTED PAPERS IN ENGLISH

DOI: http://dx.doi.org/10.18290/rh.2018.66.1-4e

\author{
DOROTA PÓŁĆWIARTEK-DREMIERRE
}

\title{
THE FIRST POLISH-FRENCH RENDEZ-VOUS OF CULTURES. HENRY III OF FRANCE'S (HENRI DE VALOIS') POLISH EPISODE
}

The first half of the $16^{\text {th }}$ century saw the formation of personal relations between Poland and France. Not too many Poles studied in France, stayed at the royal court or even travelled there, but they were often young members of distinguished families, who later held high positions in the Commonwealth of Poland and Lithuania. On the eve of the election in 1573 (following the death of Sigismund II Augustus), members of the Polish elite knew France and some spoke French, but the general public in both countries knew little of each other. ${ }^{1}$

The episode of Henri de Valois on the Polish throne is well known. That is when the solid history of Polish-French political and cultural relations began. It was not a smooth beginning. The French and Poles, nations with different cultural backgrounds, conflicting interests and dissimilar attitudes towards different faiths, got entangled in a complex diplomatic game. As a result of mutual contacts, full of misunderstandings, they did not so much get to know each other, but rather became aware of the unbidgeable gaps between them.

Dorota Pó Classical Philology and in the section History, Texts and Documents at the École Pratique des Hautes Études, Paris. Scholarship holder of the French Government. She has a degree in Lettres Modernes from Paris IV-Sorbonne and in Renaissance Studies from the Warsaw University Institute of Classical Philology; e-mail: dremierredorota@gmail.com

The Polish version of the article was published in Roczniki Humanistyczne vol. 63, issue 1 (2015).

${ }^{1}$ In King Sigismund Augustus' office and court, former students of French professors or travellers to France only play an important role. See Henryk BARYCZ, "Pod urokiem humanistycznego Paryża," in IDEM, Z dziejów polskich wędrówek naukowych za granice (Wrocław: Zakład Narodowy im. Ossolińskich, 1969), 233. 
Already during the first extensive contacts due to political reasons, i.e. the visit of Polish envoys in Paris in the summer of 1573, the French and Poles were made aware of their differences; Henri de Valois' five-month stay in Poland sparked the birth of gallophobia in Polish society. Later on, Poland, a veritable exemplar of tolerance, saw the rise of xenophobia, evidenced in literature since the late $16^{\text {th }}$ century. ${ }^{2}$ The first Polish-French rendez-vous ended in a verbal duel of spite between Philippe Desportes and his Polish counterparts. Paradoxically, Jan Kochanowski's reply, a paragon of masterful bitter irony, elevated this exchange above the political, everyday reality, to the level of dialogue between poets.

\section{POLITICS, AN INAUSPICIOUS BEGINNING}

The French tried to install Henri de Valois on the Polish throne three times in the second half of the $16^{\text {th }}$ century. Henri was the favourite son of Catherine de' Medici and brother of the then King Charles IX of France. In the early 1570 s, a member of the French royal entourage, the midget Jan Krassowski, set out on a secret mission to the Polish-Lithuanian Commonwealth to praise Henry's prowess and talents at the Polish court. A second envoy entrusted with the same mission was dispatched to Poland during the advanced stages of sickness of King Sigismund II Augustus, who had produced no heir to the throne. However, envoy Jean de Balany arrived in Krakow after the monarch's death. The final mission, involving an official presentation of Henry's candidacy to the Polish throne, was carried out by Jean de Monluc, who left for Poland in August 1572. While Monluc was on his way to Poland, the St. Bartholomew's Day massacre took place in France, which seemed to thwart the chances of Henri de Valois assuming the throne of the Polish-Lithuanian Commonwealth, a haven of religious tolerance.

The election of Henry as king of Poland was, in the early 1570s, a major stake in France's internal interests. Charles IX wanted to get rid of his brother, while Catherine de' Medici wished to see him as the king of a powerful country. From the point of view of the mother of kings, the Polish

\footnotetext{
${ }^{2}$ See Mirosław Korolko, Klejnot swobodnego sumienia. Polemika wokót konfederacji warszawskiej 1573-1658 (Warszawa: Instytut Wydawniczy Pax, 1974), 121; See also: Janusz TAzBIR, "Ksenofobia w Polsce XVI i XVII w.," in IDEM, Arianie i katolicy (Warszawa: Książka i Wiedza, 1971), 255; and IDEM, "Stosunek do obcych w dobie baroku," in Swojskość i cudzoziemszczyzna w dziejach kultury polskiej, ed. Zofia Stefanowska (Warszawa: PWN, 1973), esp. 84-87.
} 
throne was to strengthen in the eyes of French Catholic aristocracy the image of Henry as an efficient military commander (as king of Poland, Henry was to wage war on Moscow), capable of defeating the Protestants. Once Charles IX would die due to ill health, Catherine de' Medici wanted Henri de Valois to return to Paris and assume the French throne. The royal mother would not like the French throne to be assumed by her younger son, Francis de Valois, who was sympathetic towards people of various beliefs. The plan was to postpone Francis' rightful regency until Henry's return from Poland. Sending Henry to Poland, Catherine de' Medici wanted to prove that she cared of the interests of the monarchy more than she did of that of her children. This would secure both her strong position in the country and regency. ${ }^{3}$

Henry becoming the king of Poland was, then, the central element of Catherine's complex strategy of internal politics (to say nothing about the strengthening of the position of France with respect to the Habsburgs) and had nothing to do with the will to establish closer links with a northern kingdom. This political agenda determined the quality of French-Polish relations, including cultural ones. During the election, the French and the Poles were, on the one hand, forced to present their own nation to "foreigners", glossing over some less glorious aspects, and on the other hand to introduce those "foreigners" to their compatriots, assuring them that they were a most adequate political partner. Jean de Monluc took part in the creation of this fiction. The truth became apparent in the summer of 1573 .

\section{CULTURE HIATUS}

In the summer of 1573, Polish envoys set out for France to obtain the consent of the future king, Henri de Valois, for the conditions of his elections. The eleven-strong delegation included eminent humanists such as Mikołaj Firlej, Jan Zamoyski, Olbracht Łaski, Mikołaj Radziwiłł "Sierotka," and Jan Herburt. The delegation entered Paris on August 19. ${ }^{4}$ They were

\footnotetext{
${ }^{3}$ Ewa Kociszewska recreates the context of the interior interests of France of the period on the basis of analysis of the Ballet des Polonais, a performance in honour of the Polish delegation to Paris in 1573 (EADEM, "War and Seduction in Cybele's Garden: Contextualizing the Ballet des Polonais," Renaissance Quarterly, Vol. 65, No. 3 (Fall 2012): 809-63).

${ }^{4}$ Different texts provide different dates of the entry of Polish envoys to Paris. I quote after: Diariusz poselstwa polskiego do Francji po Henryka Walezego w 1573 roku, ed. Adam Przyboś,
} 
welcomed by "niemało książąt, markiezów i kontów, przy których poczet wielki ślachty" [a vast number of dukes, marquises, counts, and large delegations of nobility], by onlookers along the road, "niezliczona rzecz ludzi, która się tam była [im] ku dziwowaniu zeszła" [an innumerable crowd of people who arrived to satiate their curiosity]. ${ }^{5}$ The curiosity and the exaltation were by all means justified since, in the opinion of Charles IX's court poet Jean Dorat, Poland was "cultissima," like Rome during the reign of Augustus, and Ovid himself had his grave among the Sarmatians:

\footnotetext{
Roma sub Augusto fuit urbs cultissima quondam, Et qua Nasoni poena carare foret.

At tunc Sauromatae fuerant gens barbara contra,

Et quam Nasoni poena videre fuit.

Nunc si tam cultos is cerneret arte Polonos,

Et Romam contra barbariae similem:

Diceret Augusto, ne se revocaret in urbem:

Sauromatae Latium, Roma sit exilium. ${ }^{6}$
}

The Polish envoys, arriving from the end of the world, amazed the onlookers with their attire, culture and education. ${ }^{7}$ The fact that in the background of this image was another one, of an ice-cold and barbaric country, ${ }^{8}$ did not matter at that point. During the first official visit of Poles to Paris, the French tried to come to terms with the exotic nature of their guests, referring them to a reality of the ancient world, distant enough, mythical and yet real. In the France of the latter half of the $16^{\text {th }} \mathrm{c}$. there was no more enobling reference. This did not change the fact that it was, above all, convenient for the French monarchy and in 1573 nobody intended to confront it with reality. The ill-concealed surprise expressed in French accounts

Roman Żelewski (Wrocław-Warszawa-Kraków: Zakład Narodowy im. Ossolińskich, 1963), 106 ("Die 19 augusti/Wjachaliźmy do miasta Paryża" [We arrived in the city of Paris]).

${ }^{5}$ Both quotes: Diariusz poselstwa polskiego, 106.

${ }^{6}$ Jean DORAT, "De Roma et Polonia," in Ad amplissimos polonorum legatos, Parisiorum urbem ingredientes Io. Aurati poetae regii prosphonetici versus (Parisiis: Ex Officina Federici Morelli, 1573). On the myth of Ovid's tomb in Poland see Joseph B. TrapP, "Ovid's Tomb. The Growth of a Legend from Eusebius to Laurence Sterne, Chateaubriand and George Richmond," Journal of the Warburg and Courtauld Institutes 36 (1973): 50-76.

${ }^{7}$ See e.g. a quote from Emmanuel DE NoAILles, Henri de Valois et la Pologne, vol. II (Paris: M. Lévy frères, 1867), 354-356, in François RossET, Drzewo Kraków. Mit polski w literaturze francuskiej 1573-1896 (Kraków: Znak, 1997), 26-27.

${ }^{8}$ See e.g. François Rosset, Drzewo Kraków, 24, 33; Ewa Kociszewska, "The Sun King in the Realm of Eternal Winter. The Unknown Medal of Henri de Valois, King of Poland (1573)," French Studies Bulletin 30, No. 113 (2009): 78-82. 
of the visit concerning contacts with Polish deputies expressed confusion with and incomprehension of their differences.

Matters looked quite similar on the Polish side; what was unknown did not arouse any deeper interest. The envoys were received by Catherine de' Medici in the magnificent buildings and gardens of Paris. In the summer of 1573 in Paris one could already admire the Renaissance facades of the western and southern wings of the Louvre and a section of the Tuileries Palace. However, our eminent humanists made no mention of the magnificent architecture of the French capital in their memoirs and letters; the envoys limited themselves to enumerating the names of the places they visited. ${ }^{9}$

The quintessence of the Polish delegation members' reaction to the world of French culture was the amount of attention paid in their memoirs to the following celebrations of 15 September 1573. That day, one day after Henri de Valois was elected king of Poland, Catherine de' Medici held a solemn event in honour of the envoys; the performance went down in history as the Ballet des Polonais. ${ }^{10}$ The performance was staged by the members of the Académie de musique et de poésie, an erudite institution set up in 1570 under the auspices of Jean Antoine de Baif and Thibault de Courville, aiming at rejuvenating ancient art. The Ballet des Polonais was the outcome of the work eminent artists: Balthazar de Beaujoyeulx (Baltazarino di Belgioioso, choreography), Jean Dorat (Latin songs) and Pierre de Ronsard and

\footnotetext{
${ }^{9}$ See e.g. Diariusz poselstwa polskiego, 106-239; Ewa KocISZEwSKA, "Elekcja Henryka Walezego a polsko-francuskie relacje artystyczne i intelektualne," in Francusko-polskie relacje artystyczne w epoce nowożytnej, ed. Andrzej Pieńkos, Agnieszka Rosales-Rodriguez (Warszawa: Wydawnictwo Neriton, 2010), 18-19.

${ }^{10}$ On the Ballet des Polonais in general and in the political context, including Polish-French relations see Mark FrAnKo, "Writing Dancing, 1573," in IDEM, Dance as Text: Ideologies of the Baroque Body (Cambridge: Cambridge University Press, 1993), 15-31; Joanna PIETRZAK-ThÉBAult, "Enrico di Valois in Polonia, il trionfo dell'illusorio," in Théâtre, musique et arts dans les cours européennes de la Renaissance et du Baroque, ed. Kazimierz Sabik (Warszawa: Wydawnictwo Uniwersytetu Warszawskiego, 1997), 447-460; EADEM, "Le Ballet des Polonais," in La France et la Pologne: histoire, mythes, representations, actes du colloque des 16-17-18 septembre 1998 à l'Université Lumière-Lyon, éd. Françoise Lavocat (Lyon: Presse Universitaire de Lyon, 2000), 127-136; Florence Vuilleumier-Laurens, Pierre Laurens, "Le Bal des Polonais: Anatomie d'une description," in: Jean Dorat, poète humaniste de la Renaissance, actes du colloque international (Limoges, 6-8 juin 2001), éd. Christine de Buzon, Jean-Eudes Girot (Genève: Droz, 2007), 131-165; Ewa KociszewsKA, “Arras medycejski króla Henryka Walezego. Fêtes dla poselstwa polskiego i Henryka Walezego w ogrodach Tuileries w 1573 roku," in Urbs celeberrima. Księga pamiątkowa na 750-lecie lokacji Krakowa, ed. Andrzej Grzybkowski, Zdzisław Żygulski, Teresa Grzybkowska (Kraków: Muzeum Narodowe w Krakowie, 2008), 381-96 (the Polish translation of Chorea Nympharum, 379); EADEM, Elekcja Henryka Walezego, 13-20; EADEM, "War and Seduction," 809-63.
} 
Amadis Jamyn (French songs) ${ }^{11}$. The production was constructed on the basis of erudite references to ancient literature and French contemporary literature as well as correspondences between text and dance. The message of the performance, heavily focused on military metaphor and expressed in the choreography via complex sequences of geometrical figures, was indebted to the humanist idea of the inalienable relations between cosmic order and arithmetics, geometry and music. It moreover drew on the popular idea of the time in Paris of the relationship between geometry and military art. ${ }^{12}$ The entire show was a complex artistic and intellectual structure, which illustrated Catherine de' Medici's political aspirations.

The French were in raptures. The Ballet des Polonais was expressive of the spirit of the refined Frnech culture of the day and of the sophisticated aesthetic preferences of the French court. In his memoirs, Pierre de Bourdeille (Brantôme) lavished praise on the Ballet des Polonais, which was "le plus beau ballet qui fut jamais fait au monde." According to Agryppa d'Aubigné, the Poles were as awed as the French:

\footnotetext{
${ }^{11}$ We know the course of the performance from a variety of sources, including a commemorative issue of Magnificentissimi spectaculi [...] descriptio. Apart from a sequence of descriptions, narraties and quotes, it included a translation (by Jean Dorat) of French popems into Latin for the Polish envoys (Magnificentissimi spectaculi a regina regum matre in hortis suburbanis editi, in Henrici regis Poloniae inuictissimi nuper renunciati gratulationem, descriptio, Parisiis: Ex Officina F. Morelli, 1573). More on Dorat's account see Florence VUILLEUMIER-LAURENS, Pierre LAurens, Le Bal des Polonais, 139. The article by F. Vuilleumier-Laurens and P. Laurens (p. 139) questions the opinion aired by V.E. Graham and W. McAllister Johnson (EIDEM, The Royal Tour of France by Charles IX and Catherine de'Medici: Festivals and Entries 1564-6 (TorontoBuffalo-London: University of Toronto Press, 1979), 58, note 105); the latter claimed that Dorat's descrition was in fact "a collection of verse without any transitional or programmatic commentary." According to E. Kociszewska, the core of Magnificentissimi spectaculi... descriptio is Chorea Nympharum, a description of the nymphs' dance, which via images drawn from ancient poetry and unlike other texts written to commemorate the election of Henri de Valois, has a covert political message Ballet des Polonais; see Ewa Kociszewska, "War and Seduction," $811 \mathrm{ff}$.

${ }^{12}$ Jennifer Nevile, "Order, Proportion, and Geometric Forms: The Cosmic Structure of Dance, Grand Gardens, and Architecture during the Renaissance," in Dance, Spectacle, and the Body Politick, 1250-1750, ed. Jennifer Nevile (Bloomington: Indiana University Press, 2008), 301; Ewa KociszewsKa, "War and Seduction," 823-28; EAdEM, Arras medycejski, 382-84.

${ }^{13}$ Pierre DE BouRdeILle, "Discours II, De la Reyne Mere de nos Roys derniers Catherine de Medicis," in Memoires de Messire Pierre du Bourdeille, Seigneur de Brantome, contenant Les Vies des Dames Illustres de France de son temps (Leyde: Jean Sambix le jeune, 1665), 80-82 (an account of the performance).
} 
Les Polonais admirerent les confusions bien desmeslées, les chiffres bien formez $\mathrm{du}$ ballet, les musiques differentes, et dirent que le bal de France est chose impossible à contrefaire à tous les rois de la terre. ${ }^{14}$

As in the case of architecture, we do not find confirmation of this awe with the performance in the Poles' accounts: the description in Diariusz is limited to enumerating the successive parts of the performance. The hastily summarised songs did not inspire much interest in the envoys; nor were they thrilled by the hour-long dance of sixteen nymphs of France. ${ }^{15}$ The envoys definitely understood the literal aspect of the Ballet des Polonais as accounted for in Diariusz; we cannot be sure that they appreciated the deeper meaning of what they saw. ${ }^{16}$ The Poles did not expect the political significance of the performances

\footnotetext{
${ }^{14}$ Agryppa D’ Aubigné, Histoire universelle, vol. IV, éd. André Thierry (Genève: Droz, 19811999), 156. "Poles would marvel at such well-ordered chaos, well-formed dancing arrangements and diverse music and said that the French dance performance cannot possibly be matched by any other king in the world."

${ }^{15}$ A description of the Ballet des Polonais can be found in Diariusz poselstwa polskiego do Francji, 215-17: “[...] A zatym ona białogłowa, która na samym wierzchu siedziała, która znaczeła totum Regnum Galliae, poczęła osobliwym głosem pięknym śpiewać wiersze francuskim językiem, dziękując Królowi Polskiemu naprzód za to, iż bronieł od nieprzyjaciół to Królestwo, potym żałując jego stąd odjachania etc. Takież winszując mu dobrego i szczęśliwego panowania na tym Króliestwie; które wiersze przez godzinę spiewała. / A gdy już tego śpiewania na górze dokonała, potym druga białogłowa, która niżej na przodku siedziała z lutnią, poczęła na lutni grać i przy niej śpiewać wiersze francuskim językiem żałując discessum Króla Polskiego etc. [...] Śpiewała takież deplorując discessum Regis, a wysławiając illius heroica gesta, videlicet, że te provinciae za jego sprawą beły w pokoju zachowane, winszując potym szczęśliwego panowania etc. / [...] Tamże one w pośrzodek onej sale przyszedszy, tańce osobne i bardzo misterne tańcowały, który ich taniec trwał o godzinę, i w każdym tańcu inaksze gesty i inaksze sztuki czynieły, co beło z wielkim podziwieniem u wszech ludzi" [The comely lady who sat at the very top, who personified totum Regnum Galliae, began to sing with a uniquely charming voice verses in the French language, extending thanks to the Polish King, first of all for defending the Kingdom against her enemies, then deploring his departure from here, etc. She moreover wished him a good and auspicious reign over this Kingdom; these verses she would sing for a full hour. / Having completed her singing at the very top, then another comely lady, who was seated in the foreground with a lute, began to pluck the lute and sing verses in the French language to its tone, deploring the discessum of the Poligh King, etc. [...] She also sang deploring the discessum Regis, extolling illius heroica gesta, videlicet, that the provinciae through his action were left in peace, wishing later a happy reign, etc. / [...] There and then, gathering in the centre of the hall, they danced separately and in a most sophisticated manner, which dance was an hour long, and in each dance they made different gestures and different feats, which was greatly admired by all people in attendance]. E. Kociszewska implies that the author of Diariusz, Protestant Andrzej Górka, could have restrained in expressing his enchantment in France due to his personal dislike of Henri de Valois' election (See E. KociszEwsKA, "War and Seduction," 815).

${ }^{16}$ Monique Chatenet and Luisa Capodieci (in "Les triomphes des noces de Joyeuse (17 septembre-19 octobre 1581) à travers la correspondance diplomatique italienne et l'Epithalame de Jean Dorat," Bulletin de la Société de l'histoire de l'art français 2006: 9-54) claim that the performances
} 
staged in the French court. ${ }^{17}$ This does not mean, however, that the reaction of Agryppa d'Aubigné was not true; it may have been caused by the confusion in the face of an art so distant to Polish one and of such an exotic taste. We should not be surprised by the reaction of the Polish envoys, however, and accuse them of artistic and intellectual insensivity, since Bourdeille himself used the term "bizarre" three times in his account of the Ballet des Polonais (twice with respect to the entire show: "ballet bizarre" and "si bizarrement inventé," and once when referring to the figure created by the nymphs: "petit bataillon bizarrement inventé"). Even in his eyes the ballet illustrating a message hidden in unintelligible alusions which only a narrow circle of erudites could disambiguate made an impression of "confusion" and "desordre." 18 During their visit to Paris the envoys-Polish humanists - admired the grandiosity and splendour, remaining indifferent to the culture.

There was one exeption to the overall indifference: the Poles in Paris were thrilled by the decorative city gates and the ephemeral triumphal arches. They were able to marvel at them during their own entry to Paris through the Gate Saint Martin, on August 19, and during the entry of Henri de Valois as the Polish king through the Gate Saint Antoine, on 14 September 1573. Readers of Diariusz can identify clear admiration with such monumens of architecture and ephemeral art; the gates were described and the incriptions they bore were quoted in extenso. ${ }^{19}$ The main ephemeral Parisian gate erected to commorate the entry of Henry into Paris was designed by

held by Henry III and Catherine de' Medici were often unintelligible also for the Italian ambassadors to the French court (after Ewa KociszewsKA, "Elekcja Henryka Walezego," 20). Bourdeille's description of the ballet, however, indicates that the military metaphor must have been rather straightforward: "elles (nimfy) vindrent toutes à descendre du roc, \& s'estant mises en forme d'un petit bataillon bizarrement inventé, les violons montans jusques à une trentaine, sonnant quasi un air de guerre fort plaisant" (Pierre de BouRdeILle, Discours II, De la Reyne Mere, 81highlights D.P.-D.).

${ }^{17}$ Margaret MCGowAN, "L'Essor du ballet à la cour de Henri III," in Henri III mécène: des arts, des sciences et des lettres, éd. Isabelle de Conihout, Jean-François Maillard, Guy Poirier (Paris: Presses de l'Université Paris-Sorbonne, 2006), 88.

${ }^{18}$ Pierre de Bourdeille, Discours II, De la Reyne Mere, 81: "elles (nimfy) vindrent toutes à descendre du roc, \& s'estant mises en forme d'un petit bataillon bizarrement inventé, les violons montans jusques à une trentaine, sonnant quasi un air de guerre fort plaisant, [...] \& puis apres danserent leur ballet si bizarrement inventé, [...] si bien que tout le monde s'esbahit que par une telle confusion \& un tel desordre jamais ne defaillirent leurs ordres, [...] \& dura ce ballet bizarre pour le moins une heure"-highlights D.P.-D.

${ }^{19}$ See Diariusz poselstwa polskiego, 106-9 (gates prepared for the entry of Polish envoys) and pp. 209-14 (gates prepared in honour of King Henry of Poland). 
Antoine Caron and Germain Pilon, with poetic inscriptions by Ronsard. When Henry arrived in Krakow in February 1574, the first ephemeral triumphal arch on Polish soil was erected for him. ${ }^{20}$ Poles recreated the gate in Paris, adorning it with an eagle of their own creation, which fluttered its wings when Henry was passing through the gate. The poems on the arch were composed by Jan Kochanowski. Ever since, ephemeral triumphal gates were an indispensable element of the solemn entries of monarchs into towns across the Commonwealth of Poland and Lithuania. ${ }^{21}$

The Polish-French culture dialogue in 1573 began and finished with official celebrations. The differences and misunderstandings were dealt with by representatives of both nationalities by a safe désintéressement. The situation was much worse in Krakow: Henry's court was given to revelries that scandalised the Poles and the Polish nobility were disregarded by the monarch; there were night assaults with casualties. ${ }^{22}$ The initial lack of understanding bordering on awe transformed on both sides during Henri de Valois' stay in Poland into overt lack of understading bordering on aversion. After Henry's escape from Poland, the French-Polish animosities reached their apogee.

\footnotetext{
${ }^{20}$ Ewa KociszewsKA, "Elekcja Henryka Walezego," 19; See also Irena MAMCZARZ, "Il solenne ingresso di Enrico di Valois in Polonia (1574). Alcuni aspetti delle feste rinascimentali polacche," Ricerche slavistiche 13 (1965): 64-119; Juliusz A. CHROŚCICKI, “Architektura okazjonalna XVI-XVIII wieku w Polsce. Próba charakterystyki," in Treści dzieła sztuki, proceedings from a session of Stowarzyszenie Historyków Sztuki, Gdańsk, December 1966 (Warszawa: PWN, 1969), 219-230.

${ }^{21}$ French influcens were visible e.g. in the setting of the celebration inspired by Jan Zamoyski, commemorating King Sigismund III's entry to Krakow in 1587. See Karolina TARGOsz, "Oprawa artystyczno-ideowa wjazdów weselnych trzech sióstr Habsburżanek (Kraków 1592 i 1605, Florencja 1608)," in Theatrum ceremoniale na dworze królów i książat polskich, proceedings from a conference held by the Wawel Royal Castle and Jagiellonian University Institute of History, 2325 March 1998, ed. Mariusz Markiewicz, Ryszard Skowron (Kraków: Zamek Królewski na Wawelu, 1999), 212-13; See also Juliusz CHROŚCICKI, "Barokowa architektura okazjonalna," in Wiek XVII-Kontrreformacja-Barok. Prace z historii kultury, ed. Janusz Pelc, (Wrocław: Zakład Narodowy im. Ossolińskich, 1970), 229-54 (esp. pp. 236-46, a study of the triumphal arches erected for the entry of Marie Louise Gonzaga to Gdańsk, 11 February 1646; despite having to endure freezing cold for a few hours, Marie Louise was enchanted with Gdańsk).

${ }^{22}$ Henryk Walezy's stay in Krakow describes Stanisław Kot in Adieu à la Pologne, in a reprint from Silva Rerum 5 (1930), 4/7 (Kraków: Drukarnia W.L. Anczyca, 1930), 4-6; Janusz TAzBIR, "L'Opinion polonaise après la fuite," in Henri III et son temps, éd. Robert Sauzet (Paris: Vrin, 1992), 72-73.
} 


\section{DESPORTES AND KOCHANOWSKI, A DIALOGUE OF POETS}

The escape of the French court from Krakow, or rather its intention or only a poetic fantasy, was paradoxically an opportunity for an ephemeral exchange between the leading poets of both countries, Philippe Desportes and Jan Kochanowski. Desportes was the first to start. Still, before the end of May or in early June $1574^{23}$ (the news of Charles IX's death reached Krakow on June 14 and the escape of Henry with his court took place on the night of June 19), the Frenchman wrote a malicious Adieu à la Pologne (published in Paris by Robert Estienne in 1576). ${ }^{24} \mathrm{He}$ would castigate all the vices that he could identify in Poles during his stay in Poland and expressed his misery arising from this stay away from his home country. Most probably at the end of 1575, Adieu à la Pologne reached Poland without the author's name and was taken very seriously and literally. It was translated by an anonymous translator into Latin as Valedictio Poloniae per quendam Gallum, then from Latin into Polish as Francuz do Polskiej zegnajac ja in anno 1574. Emotions were running high and probably made the anonymous translator into Latin add to the original some pejorative adjectives ("tetra," v. 1 and 8; "damnata," v. 3; "ridicula," v. 28), which augmented the negative message of Desportes' poem. ${ }^{25}$ The first reply to Adieu à la Pologne, or Odpowiedź przez Polaka wszetecznemu Francuzowi, was provided by an anonymous poet, a Protestant, most likely the author of the Polish translation of Desportes text; he undermined the French calumnies one by one. ${ }^{26}$

Polish national pride, hurt the second time (after Henry's escape from Poland), prevented any distance and the literal reading obscured the more profound poetic meaning; Desportes-as-Frenchman did not enjoy the privilege

\footnotetext{
${ }^{23}$ Wiktor WeinTRaub, "Kochanowski versus Desportes. A Sixteenth-Century French-Polish Poetic Duel," in Symbolae in honorem Georgii Y. Shevelov (München: Universitas Libera Ucrainensis Facultas Philosophica, 1971), 467 (in Polish: IDEM, "Poetycki pojedynek z Desportes'em," in IDEM, Rzecz czarnoleska (Kraków: Wydawnictwo Literackie, 1977), 358-74).

${ }^{24}$ For basic information on Adieu à la Pologne and Polish responses as well as texts and translations see: Stanisław Koт, Adieu; for an indepth analysis of Adieu à la Pologne and Gallo

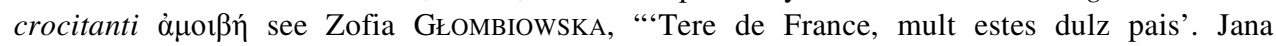
Kochanowskiego spotkania z Francją," in EADEM, W poszukiwaniu znaczeń: o poezji Jana Kochanowskiego (Gdańsk: Wydawnictwo Uniwersytetu Gdańskiego, 2001), 74-93; See also: Juliusz NowAK-DŁUŻEWSKI, Okolicznościowa poezja polityczna $w$ Polsce: pierwsi królowie elekcyjni (Warszawa: PAX, 1969), 80-86.

${ }^{25}$ Cf. Zofia GŁombiowska, "Tere de France," 74-75.

${ }^{26} \mathrm{~W}$. Weintraub refers to Odpowiedź przez. Polaka wszetecznemu Francuzowi: "And it is not free from a certain naïveté" (See IDEM, Kochanowski versus Desportes, 469).
} 
of being read as Desportes-as-poet, whom he precisely and primarily was, his Adieu à la Pologne being poetry. The poetry of the $16^{\text {th }}$ century continued to be in dialogue with the poetic legacy of Antiquity and Desportes was no exception. His contemporaries were oblivious of this dialogue in Adieu à la Pologne.

The successive motifs of Desportes' poem describing Poland, i.e. severe winters, the barbarian inhabitants clad in animal hides, the barren lands, come from an account of miseries of Ovid's exile which was suffered, like Desportes, among the "barbaria", among the "Sauromatae [...], fera gens" (Trist., III, 10, v. 4-5). ${ }^{27}$ Apart from other possible reasons for penning Adieu à la Pologne (malice, the desire to humour the king or to blame Henry's escape on Poles themselves) ${ }^{28}$ Desportes, a conscious poet, took advantage of his visit to the country where Ovid's earthly remains were buried to transform his life experience into Ovid's exilium. ${ }^{29}$ The fifty-four verses of Adieu à la Pologne is a condensation of the topoi of exile from Tristia and Epistulae ex Ponto. The perspective of dialogue with Antiquity shifts the main focus of Adieu à la Pologne from low-brow calumnies flung at Poland to the construction of the image of Desportes as a poet in exile. ${ }^{30}$ What is at stake here is a poetic motif, but it cannot be ruled out that, faced with a prospective return to France, Desportes was already intent on winning the favours of the French court in order to remain the official poet of the monarchy. ${ }^{31}$

Contrasted with the literal Odpowiedź przez Polaka wszetecznemu Francuzowi is the Gallo crocitanti $\alpha \mu o » \beta \eta$ by Jan Kochanowski, or the second reply to Desportes' poem, penned in 1576, a period of relative peace and quiet, when a second royal election was underway in Poland.

\footnotetext{
${ }^{27}$ The Ovidian intertextuality of Adieu à la Pologne was notied by Henri Lamarque, See "L'Imitation d'Ovide dans 'L'Adieu à la Pologne' de Philippe Desportes," in Ovide en France dans la Renaissance, éd. Henri Lamarque, André Baïche (Toulouse: Université de Toulouse le Mirail, 1981), 59-77. The subject was raised and elaborated on, incl. the relations between Adieu à la Pologne and Gallo crocitanti à $\mu$ oı $\beta \eta$, by Rory Finnin in his article "Attendants to the Duel: Classical Intertexts in Philippe Desportes's 'Adieu à la Pologne' and Jan Kochanowski's 'Gallo Crocitanti'," Comparative Literature Studies 44 No. 4 (2007): 458-83.

${ }^{28}$ Zofia GŁombiowska, "Tere de France," 76.

${ }^{29}$ Henri Lamarque observes à propos Adieu à la Pologne: "Tous voulaient avoir leur exil et ainsi le séjour forcé d'Ovide sur les bords de la mer Noire devenait un thème littéraire", See IDEM, L'Imitation d'Ovide, 67.

${ }^{30}$ This is put forth by R. Finnin in his article, "Attendants to the Duel."

${ }^{31}$ André BAÏche, La naissance du baroque français. Poésie et image de la Pléiade à Jean de La Ceppède (Toulouse: L'Université de Toulouse-Le Mirail, 1976), 173; See also Rory Finnin, "Attendants to the Duel," 466.
} 
Kochanowski most likely did not know French in the manner allowing him to glean the covert message of poems. ${ }^{32}$ There is no way of knowing if he had access to or even knew of the existence of the French original of Adieu à la Pologne. He read Desportes' poem in its Latin translation, Valedictio Poloniae per quendam Gallum, and replied to this text, quoting some of its verses verbatim in Gallo crocitanti à $\mu$ oı $\beta$. How much of the original Adieu à la Pologne was Kochanowski able to read in Valedictio Poloniae? The Latin version of Adieu à la Pologne is a rather precise rendition. Apart from the above three added pejorative adjectives, the changes with respect to the original arose mainly from the care of faithful transformation of the message, hence extended explicatory excerpts (e.g. in v. 15 "lupis coiisse immitibus agnos," explaining "l'âge d'or," v. 11 in Desportes or verses 29-30, to translate v. 24 in Desportes). Was Kochanowski able to capture the Ovidian intertextuality in the Latin translation of the original? These are the examples of correspondences between the original, its Latin translation and relevant excerpts from Ovid: ${ }^{33}$

\begin{tabular}{|l|l|l|}
\cline { 2 - 3 } \multicolumn{1}{c|}{ Adieu à la Pologne } & $\begin{array}{c}\text { Valedictio Poloniae per quen- } \\
\text { dam Gallum }\end{array}$ & \multicolumn{1}{c|}{ Excerpts from Ovid } \\
\cline { 2 - 2 } $\begin{array}{l}\text { "plaines desertes / Tousiours } \\
\text { de neige ou de glace cou- } \\
\text { uertes"34 (v. 1-2) }\end{array}$ & $\begin{array}{l}\text { "plena Polonia tantum / Desertis } \\
\text { [...] / Aeterno damnata gelu ni- } \\
\text { viumque perenni",35 (v. 1-3) }\end{array}$ & $\begin{array}{l}\text { "Nix iacet, et iactem ne sol } \\
\text { pluuiaeque resoluant, / indurat } \\
\text { Boreas perpetuamque facit" } \\
\text { (Trist., III, 10, 13-14) }\end{array}$ \\
\hline
\end{tabular}

\footnotetext{
${ }^{32}$ Kochanowski may have read French texts to the extent he was aided by his knowledge of Latin and Italian. For a debate on Kochanowski's being able to read French or not see e.g.: Stanisław Kot, Adieu, 20; J. Pelc, Jana Kochanowskiego wycieczka, 100; Wiktor WeInTRAub, "O przerzutniach Kochanowskiego i ich włoskich wzorach," in Rzecz czarnoleska (Kraków: Wydawnictwo Literackie, 1977), 334; Stanisław WIndAKIEwICZ, Jan Kochanowski, 22; Maciej ŻURowsKI, "Twórczość Kochanowskiego," in Między renesansem a awangarda, 23; Zofia GŁOMBIOwsKA, "Tere de France," 72-73.

${ }^{33}$ I refer to the correspondences between the text of Adieu à la Pologne and excerpts of Ovid' poetry after: R. Finnin ("Attendants to the Duel," 463-65). In his article the author does not take into account the intermediary text between Adieu à la Pologne and Gallo crocitanti à $\mu$ oı $\beta$, i.e. Valedictio Poloniae.

${ }^{34}$ Adieu à la Pologne quoted after: Stanisław Koт, Adieu, 7-8 (a faithful reprint from Desportes' original, where Adieu à la Pologne came out for the first time, in 1576, Les premieres oevvres de Philippes Des Portes au Roy de France et de Pologne (Paris: Robert Le Mangnier, 1576), charts 209-10).

${ }^{35}$ Valedictio Poloniae quoted after: Stanisław Kот, Adieu, 10-11 (the text from a manuscript from S. Kot's private holdings, with reference to manuscripts No. 168 and No. 1042 from the Ossoliński collection).
} 


\begin{tabular}{|c|c|c|}
\hline $\begin{array}{l}\text { "Ton air, tes meurs, m'ont si } \\
\text { fort sceu desplaire, / Qu'il } \\
\text { faudra bien que tout me soit } \\
\text { contraire, / Si iamais plus ie } \\
\text { retourne en ce lieu. / Adieu } \\
\text { maisons d' admirable } \\
\text { structure" (v. 4-7) }\end{array}$ & $\begin{array}{l}\text { "tantum coelumque solumque / } \\
\text { Et mores placuere tui, prius } \\
\text { omnia nostris / Ut fieri possint et } \\
\text { erunt contraria votis, / Quam fue- } \\
\text { rint quae me reducem tibi } \\
\text { tempora sistant. / [...] et vos } \\
\text { miranda domorum/tecta" } \\
\text { (v. 4-9) }\end{array}$ & $\begin{array}{l}\text { "Quem mihi nunc animum dira } \\
\text { regione iacenti / inter Sauro- } \\
\text { matas esse Getasque putes? / } \\
\text { Nec caelum patior, nec aquis } \\
\text { adsueuimus istis, / terraque } \\
\text { nescioquo non placet ipsa } \\
\text { modo. / Non domus apta satis } \\
\text { (Trist., III, 3, 5-9) }\end{array}$ \\
\hline $\begin{array}{l}\text { "Barbare peuple, arrogant et } \\
\text { volage" (v. 19) }\end{array}$ & "Barbara gens et vana" (v. 23) & $\begin{array}{l}\text { "me sciat in media uiuere } \\
\text { barbaria. / Sauromatae cingunt, } \\
\text { fera gens" (Trist., III, 10, 4-5) }\end{array}$ \\
\hline $\begin{array}{l}\text { "Puis comme un Mars veut } \\
\text { estre renommé" (v. 23) }\end{array}$ & $\begin{array}{l}\text { "his clara merentur / Nomina et } \\
\text { hisce cient Gradivum in proelia } \\
\text { patrem" (v. 29-30) }\end{array}$ & $\begin{array}{l}\text { "Sarmaticae maior Geticaeque } \\
\text { frequentia gentis / per medias } \\
\text { in equis itque reditque uias. / In } \\
\text { quibus est nemo, qui non cory- } \\
\text { ton et arcum / telaque uipereo } \\
\text { lurida felle gerat. / Vox fera, } \\
\text { trux uultus, uerissima Martis } \\
\text { imago" (Trist., V, 7, 13-17) }\end{array}$ \\
\hline "Vos peaux de loup" (v. 26) & "exuviaeque luporum” (v. 33) & $\begin{array}{l}\text { "Pellibus et sutis arcent mala } \\
\text { frigora bracis" (Trist., III, 10, } \\
\text { 19) }\end{array}$ \\
\hline $\begin{array}{l}\text { "La pauureté seulement vous } \\
\text { defend. / Si votre terre estoit } \\
\text { mieux cultiuee" (v. 30-31) }\end{array}$ & $\begin{array}{l}\text { "Paupertas haec vestra facit, } \\
\text { quam despicit hostis. / [...] si } \\
\text { culta novalia [...] / Ulla foret" } \\
\text { (v. 37-39) }\end{array}$ & $\begin{array}{l}\text { "ruris opes paruae, pecus et } \\
\text { stridentia plaustra, / et quas } \\
\text { diuitias incola pauper habet" } \\
\text { (Trist., III, 10, 57-58) }\end{array}$ \\
\hline
\end{tabular}

Adieu à la Pologne imitates Ovid's topoi rather than his lexis, which due to the use of the French language would have been imprecise anyway. In order for Kochanowski, the ideal reader ${ }^{36}$ of Desportes, to discern via the Latin translation the dialogue of Adieu à la Pologne with Ovid under the surface of insults, it was necessary that the Latin version be as close to the original precisely at the level of topoi. The above table proves that Valedictio Poloniae per quendam Gallum meets this criterion. At the same time, an absence

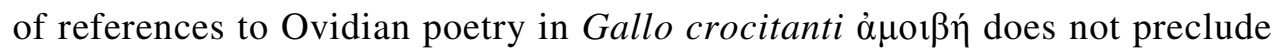
Kochanowski's reading Ovid's intertext: the use of the same sources would have been tantamount to emulating Desportes, which Gallo crocitanti $\dot{\alpha} \mu o ı \beta$ does not concentrate on.

'A $\mu$ oı $\beta$ is a recompense, an exchange or a reply to a letter. In the poetic world, $\dot{\alpha} \mu$ oı $\beta \eta$ invokes the world of the bucolics. Central to Gallo crocitanti

\footnotetext{
${ }^{36}$ The term used by Rory Finnin (“Attendants to the Duel,” 467).
} 
$\dot{\alpha} \mu$ oı $\beta \dot{~ i s ~ n o t ~ s o ~ m u c h ~ a ~ l i t e r a l ~ c o u n t e r a t t a c k ~ b u t ~ a ~ p o l e m i c ~ w i t h ~ D e s p o r t e s ~ a t ~}$ the literary level, which leads to a clash of two visions of Polish-French events of 1574, as well as two divergent poetical concepts. The first verse of Gallo crocitanti $\dot{\alpha} \mu o » \beta \eta$ ("Et tamen hanc poteras mecum requiescere noctem") is a nearly verbatim quote from Virgil's first eclogue (Ecl. I, 79, "Hic tamen hanc mecum poteras requiescere noctem"). ${ }^{37}$ These words are uttered in the bucolic by Tiresias, the happy old man who lives on his own land in peace and quiet. He addresses Melibeus, a shepherd exiled from his homeland. Kochanowski meets Desportes at a place he himself took in exile and, in the guise of Tiresias, feels sorry for Desportes-Melibeus in his exilium, reversing the roles of the victor and the victim. The bucolic exile of the shepherd may be a conscious response to the topos of Ovid's exile. One way or another, Kochanowski contrasts an elegiaic Ovid with a bucolic one, and in the further section of the poem also with an epic Virgil, and ironically highlights the aspirations of the French through references to the Eneid. Kochanowski builds his commentary on the 1574 events indirectly, not via the literal nature of the similies but through references to their context. This takes place, for instance, in references to the story of Attis' transformation into a woman; the name Attis is not used but single words (highlighted D.P.-D.) point to Catullus, $63^{38}$ :

\begin{tabular}{|c|c|}
\hline Catullus, 63 (v. 12-13; 27-30) & Gallo crocitanti $\dot{\alpha} \mu \mathrm{o} \beta \eta ́$ (v. 29-34) \\
\hline $\begin{array}{l}\text { Agite ite ad alta, Gallae, Cybeles nemora } \\
\text { simul, Simul ite, Dindymenae dominae vaga } \\
\text { pecora [...] Simul haec comitibus Attis cecinit } \\
\text { notha mulier, Thiasus repente linguis trepi- } \\
\text { dantibus ululat, Leve tympanum remugit, } \\
\text { cava cymbala recrepant, Viridem citus adit } \\
\text { Idam properante pede chorus. }\end{array}$ & $\begin{array}{l}\text { Galli, inquam, quaerite coelum Mitius, et } \\
\text { patriam cursum convertite ad Idam, Tympana } \\
\text { quo raucoque vocat vos tibia cantu, Et thiasus } \\
\text { tremulis ululans per Dindyma linguis, Ite } \\
\text { sacrum aucturi numerum, famulique Cybelles, } \\
\text { Magnam semimari matrem stipate corona. }\end{array}$ \\
\hline
\end{tabular}

The frenzy of mystery celebrations in honour of goddess Cybele points to the frenetic escape of the French, while the self-inflicted injury of Attis corresponds to the effemination of the Galls.

\footnotetext{
${ }^{37}$ For a detailed interpretation of referfences of Gallo Crocitanti to ancient poetry; see Zofia GŁombiowsKa, "Tere de France," 77-93 and Rory Finnin, "Attendants to the Duel," 472-78.

${ }^{38}$ See Wiktor Weintraub, Kochanowski versus Desportes," 471-72; in the context of Catullus, the noun "gallus" - a cock, a Frenchman, acquires a new meaning in the pun of Gallo crocitanti $\alpha \dot{\alpha} \mu о \imath \beta \dot{\eta}$, a castrate.
} 
Through the sophisticated use of the context of Latin similies, in dialogue with Adieu à la Pologne, Kochanowski introduces autotelic reflection into his poem. Kochanowski's reply counters, moreover a vision of poetry represented by Desportes. He counters a slight imitation aimed at a poetic rendition of one's own ego with a humanist concept of open poetry, based on an intimate dialogue with veteres, mindful of the seriousness of the status of poetry and of its educational function. ${ }^{39}$

On the French side this early dialogue could not possibly produce any effects. Gallo crocitanti $\alpha \mu$ เ $\beta \eta \dot{~ w a s ~ m o s t ~ l i k e l y ~ n e v e r ~ r e a d ~ b y ~ D e s p o r t e s ; ~}$ Kochanowski did not publish his text (nor did he publish another of his antiFrench poems, De electione, coronatione et fuga Galli $\left[\right.$ late 1574] ${ }^{40}$ ). Gallo crocitanti $\dot{\alpha} \mu \mathrm{o} \beta \eta \dot{~ c a m e ~ o u t ~ i n ~ p r i n t ~ o n l y ~ i n ~ t h e ~ L y r i c o r u m ~ l i b e l l u s, ~ i n ~} 1612$, after Desportes' death.

In the first Polish-French encounter of cultures, the exchange between two renowned poets was the final gaze at each other. The conclusion resulting from this look gives a succinct picture of the impossibility of real PolishFrench communion during the short reign of Henri de Valois in the field of literary culture and culture in general. The language gap was only an apparent problem. What was more important, however, was the difference in the development of poetic and aesthetic ideas. In the second half of the $16^{\text {th }}$ century, France was strongly focused on the resurrection of Antiquity in its national variety, both in French poetry and in the visual arts. Therefore, the French could not possibly be impressed by the achievements of Polish Renaissance, which in its best projects came close to Italian humanism. Additionally, in the person of Desportes, French poetry was already moving in a completely different direction; his mannerism précieux was another step away from a humanistic approach to poetry, which Kochanowski aptly noticed. Eventually, however, the rejection of Desportes' malice was for Kochanowski yet another opportunity for a dialogue with the poetic legacy. Desportes did the same in his Adieu à la Pologne. Despite the lack of common ground in culture and politics, despite the divergent approaches to the shape and direction of poetry's development, the failure from the time of Henry's reign brings out the fact that Kochanowski accepted Desportes'

\footnotetext{
${ }^{39}$ Cf. the conclusion of the article by R. Finnin (“Attendants to the Duel," 479-80).

${ }^{40}$ Published in Musae reduces. Anthologie de la poésie latine à la Renaissance, vol. II (Leiden: E.J. Brill, 1975), 76-80; earlier Grzegorz E. SAENGER, "Dwie pietierburgskija rukopisy łatinskich stichotworienij Jana Kochanowskiego," Zapiski Impieratorskoy Akadiemii Nauk, [Petersburg], series VIII, vol. VII, 1 (1905): 6-8.
} 
challenge at the artistic level; the Polish-French dialogue flourished for a short spell only over a cultural ravine.

\section{BIBLIOGRAPHY}

Aubigné, Agrippa d'. Histoire universelle, vol. IV, édited by André Thierry. Genève: Droz, 1981-1999.

BAïchE, André. La naissance du baroque français. Poésie et image de la Pléiade à Jean de La Ceppède. Toulouse: L'Université de Toulouse-Le Mirail, 1976.

BARYCZ, Henryk. "Pod urokiem humanistycznego Paryża" [Under the spell of the humanist Paris]. In IDEM. Z dziejów polskich wędrówek naukowych za granice [From the history of journeys abroad by Polish scholars], 211-242. Wrocław: Ossolineum, 1969.

BourdeILle, Pierre de. "Discours II, De la Reyne Mere de nos Roys derniers Catherine de Medicis." In Memoires de Messire Pierre du Bourdeille, Seigneur de Brantome, contenant Les Vies des Dames Illustres de France de son temps. Leyde: Jean Sambix le jeune, 1665.

Chatenet, Monique, Luisa CAPODieCi. "Les triomphes des noces de Joyeuse (17 septembre-19 octobre 1581) à travers la correspondance diplomatique italienne et l'Epithalame de Jean Dorat." Bulletin de la Société de l'histoire de l'art français (2006): 9-54.

ChroścICKI, Juliusz. “Architektura okazjonalna XVI-XVIII wieku w Polsce. Próba charakterystyki" [Ephemeral architecture of the $16^{\text {th }}-18^{\text {th }} \mathrm{c}$. in Poland. An outline]. In Treści dzieta sztuki [The contents of a work of art], proceedings from a session of Stowarzyszenie Historyków Sztuki, Gdańsk 1966. Warszawa: PWN, 1969.

CHROŚCICKI, Juliusz. "Barokowa architektura okazjonalna" [Baroque ephemeral architecture]. In Wiek XVII-Kontrreformacja-Barok. Prace $z$ historii kultury [The $17^{\text {th }}$ c.-Counter Reformation-Baroque. Texts in culture history], edited by Janusz Pelc, 229-54. Wrocław: Zakład Narodowy im. Ossolińskich, 1970.

DesPortes, Philippe. Les premieres oevvres de Philippes Des Portes au Roy de France et de Pologne. Paris: Robert Le Mangnier, 1576.

Diariusz poselstwa polskiego do Francji po Henryka Walezego w 1573 roku [Diary of the delegation of Polish envoys to France for Henri de Valois in 1573], edited by Adam Przyboś, Roman Żelewski. Wrocław-Warszawa-Kraków: Ossolineum, 1963.

DoRAt, Jean. Ad amplissimos polonorum legatos, Parisiorum urbem ingredientes Io. Aurati poetae regii prosphonetici versus. Parisiis: Ex Officina Federici Morelli, 1573.

FInNIN, Rory. "Attendants to the Duel: Classical Intertexts in Philippe Desportes's 'Adieu à la Pologne' and Jan Kochanowski's 'Gallo Crocitanti'." Comparative Literature Studies 44, No. 4 (2007): 458-83.

Franko, Mark. Writing Dancing, 1573. In IDEM. Dance as Text: Ideologies of the Baroque Body, 15-31. Cambridge: Cambridge University Press, 1993.

GŁombiowska, Zofia. “'Tere de France, mult estes dulz pais’. Jana Kochanowskiego spotkania z Francją" ["Tere de France, mult estes dulz pais. Jan Kochanowski's encounters with France]. In EADEM. W poszukiwaniu znaczeń: o poezji Jana Kochanowskiego [In search of meaning: on the poetry of Jan Kochanowski], 63-104. Gdańsk: Wydawnictwo Uniwersytetu Gdańskiego, 2001. 
GrahAM, Victor Ernest, Johnson W. MCAlLISTER. The Royal Tour of France by Charles IX and Catherine de'Medici: Festivals and Entries 1564-6. Toronto-Buffalo-London: University of Toronto Press, 1979.

Kociszewska, Ewa. “Arras medycejski króla Henryka Walezego. Fêtes dla poselstwa polskiego i Henryka Walezego w ogrodach Tuileries w 1573 roku” [King Henri de Valois' de' Medici's tapestry. Fêtes for the Polish envoys and Henri de Valois in the Tuileries Gardens in 1573]. In Urbs celeberrima. Księga pamiatkowa na 750-lecie lokacji Krakowa [Urbs celeberrima. A commemorative book for the $750^{\text {th }}$ anniversary of the foundation of Krakow], edited by Andrzej Grzybkowski, Zdzisław Żygulski, Teresa Grzybkowska, 381-96. Kraków: Muzeum Narodowe w Krakowie, 2008.

Kociszewska, Ewa. "Elekcja Henryka Walezego a polsko-francuskie relacje artystyczne i intelektualne" [Henri de Valois' election and the Polish-French artistic and intellectual relations]. In Francusko-polskie relacje artystyczne $w$ epoce nowożytnej [The French-Polish artistic relations of the modern era], edited by Andrzej Pieńkos, Agnieszka Rosales-Rodriguez, 13-20. Warszawa: Wydawnictwo Neriton, 2010.

Kociszewska, Ewa. "The Sun King in the Realm of Eternal Winter. The Unknown Medal of Henri de Valois, King of Poland (1573)." French Studies Bulletin 30, No. 113 (2009): 78-82.

KociszewsKa, Ewa. "War and Seduction in Cybele's Garden: Contextualizing the Ballet des Polonais." Renaissance Quarterly 65, No. 3 (2012): 809-63.

Korolko, Mirosław. Klejnot swobodnego sumienia. Polemika wokót konfederacji warszawskiej 1573-1658 [The jewel of a free conscience. A polemic about the Warsaw Confederation of 1573-1658]. Warszawa: Instytut Wydawniczy Pax, 1974.

Kot, Stanisław. “Adieu à la Pologne.” In reprint from Silva Rerum 5, No. 4/7 (1930).

Lamarque, Henri. “L'Imitation d'Ovide dans 'L'Adieu à la Pologne' de Philippe Desportes.” In Ovide en France dans la Renaissance, édited by Henri Lamarque, André Baïche, 59-77. Toulouse: Université de Toulouse le Mirail, 1981.

Magnificentissimi spectaculi a regina regum matre in hortis suburbanis editi, in Henrici regis Poloniae inuictissimi nuper renunciati gratulationem, descriptio. Parisiis: Ex Officina F. Morelli, 1573.

MAmCZARZ, Irena. "Il solenne ingresso di Enrico di Valois in Polonia (1574). Alcuni aspetti delle feste rinascimentali polacche." Ricerche slavistiche 13 (1965): 64-119.

McGowan, Margaret. "L'Essor du ballet à la cour de Henri III.” In Henri III mécène: des arts, des sciences et des lettres, edited by Isabelle de Conihout, Jean-François Maillard, Guy Poirier, 81-89. Paris: Presses de l'Université Paris-Sorbonne, 2006.

Musae reduces. Anthologie de la poésie latine à la Renaissance, vol. II, edited by Pierre Laurens, Claudie Balavoine. Leiden: Brill, 1975.

Nevile, Jennifer. "Order, Proportion, and Geometric Forms: The Cosmic Structure of Dance, Grand Gardens, and Architecture during the Renaissance." In Dance, Spectacle, and the Body Politick, 1250-1750, edited by Jennifer Nevile, 295-312. Bloomington: Indiana University Press, 2008.

NoAilles, Emmanuel de. Henri de Valois et la Pologne, vol. I-II. Paris: Michel Lévy Frères, 1867.

NowAK-DŁUŻEwSKI, Juliusz. Okolicznościowa poezja polityczna w Polsce: pierwsi królowie elekcyjni [Commemorative political poetryin Poland: the first elective monarchs]. Warszawa: PAX, 1969.

PelC, Janusz. "Jana Kochanowskiego wycieczka do Francji” [Jan Kochanowski's trip to France]. Prace polonistyczne 32 (1976): 93-103. 
PietrZak-Thébault, Joanna. "Enrico di Valois in Polonia, il trionfo dell'illusorio." In Théâtre, musique et arts dans les cours européennes de la Renaissance et du Baroque, edited by Kazimierz Sabik, 447-60. Warszawa: Wydawnictwo Uniwersytetu Warszawskiego, 1997.

PietrZaK-Thébault, Joanna. "Le Ballet des Polonais." In La France et la Pologne: histoire, mythes, representations, actes du colloque des 16-17-18 septembre 1998 à l'Université Lumière-Lyon, edited by Françoise Lavocat, 127-36. Lyon: Presse Universitaire de Lyon, 2000.

RossET, François. Drzewo Kraków. Mit polski w literaturze francuskiej 1573-1896 [The tree Krakow. The Polish myth in French literature 1573-1896]. Kraków: Znak, 1997.

TARGOSZ, Karolina. "Oprawa artystyczno-ideowa wjazdów weselnych trzech sióstr Habsburżanek (Kraków 1592 i 1605, Florencja 1608)" [The artistic and ideological setting of wedding entries of three Habsburg sisters (Krakow 1592 and 1605, Florence 1608)]. In Theatrum ceremoniale na dworze królów i ksiąząt polskich [Theatrum ceremoniale at the court of Polish kings and princes], proceedings from a conference held by the Wawel Royal Castle and Jagiellonian University Institute of History, 23-25 March 1998, edited by Mariusz Markiewicz, Ryszard Skowron, 207-43. Kraków: Zamek Królewski na Wawelu, 1999.

TAZBIR, Janunsz. “L'Opinion polonaise après la fuite. Henri de Valois aux yeux de ses sujets.” In Henri III et son temps, edited by Robert Sauzet, 69-86. Paris: Vrin, 1992.

TAZBIR, Janusz. "Ksenofobia w Polsce XVI i XVII w." [Xenophobia in Poland in the $16^{\text {th }}$ and $17^{\text {th }}$ c.]. In IDEM. Arianie $i$ katolicy [The Polish Brethren and Catholics], 238-78. Warszawa: Książka i Wiedza, 1971.

TAZBIR, Janusz. "Stosunek do obcych w dobie baroku" [The approach to foreigners in the Baroque]. In Swojskość i cudzoziemszczyzna w dziejach kultury polskiej [Domesticity and foreignness in the history of Polish culture], edited by Zofia Stefanowska, 80-112. Warszawa: PWN, 1973.

Trapp, Joseph B. "Ovid's Tomb. The Growth of a Legend from Eusebius to Laurence Sterne, Chateaubriand and George Richmond." Journal of the Warburg and Courtauld Institutes 36 (1973): 50-76.

Vuilleumier-Laurens, Florence, Pierre Laurens. "Le Bal des Polonais: Anatomie d'une description." In Jean Dorat, poète humaniste de la Renaissance, actes du colloque international (Limoges, 6-8 juin 2001), edited by Christine de Buzon, Jean-Eudes Girot, 131-65. Genève: Droz, 2007.

Weintraub, Wiktor. "Kochanowski versus Desportes. A Sixteenth-Century French-Polish Poetic Duel." In Symbolae in honorem Georgii Y. Shevelov, edited by William E. Harkins; Jurij Ševel'ov. München: Universitas Libera Ucrainensis Facultas Philosophica, 1971. (In Polish: "Poetycki pojedynek z Desportes'em" [A poetic duel with Desportes]. In IDEM. Rzecz czarnoleska [On Czarnolas], 358-74. Kraków: Wydawnictwo Literackie, 1977).

WeINTRAub, Wiktor. Rzecz czarnoleska, Kraków: Wydawnictwo Literackie, 1977.

WindAKIEwICZ, Stanisław. Jan Kochanowski. Warszawa: Czytelnik, 1947.

ŻURowsKI, Maciej. "Twórczość Kochanowskiego i dynamika poezji europejskiej XVI wieku” [The art of Jan Kochanowski and the dynamism of European poetry in the $16^{\text {th }}$ century]. In Między renesansem a awangarda, o literaturze europejskiej z perspektywy komparatysty [Between the Renaissance and the avant-garde; on European literature from the comparatist's perspective], edited by Maciej Żurowski, Henryk Chudak, 15-28. Warszawa: PWN, 2007. 


\section{THE FIRST POLISH-FRENCH RENDEZ-VOUS OF CULTURES. HENRY III OF FRANCE'S (HENRI DE VALOIS') POLISH EPISODE}

\section{Summary}

A complex political game, differences in the level of development of political, social and aesthetic thought, different customs, and also frequently a language gap —all of these conspired against the Polish-French dialogue in the sphere of culture in the years 1573-1574. The article analyzes the opportunities for both parties to get to know each other during the Polish episode of Henri de Valois: a visit by the Polish group of envoys to Paris in the summer of 1573, and a poetical exchange between Philippe Desportes and Poles, including Jan Kochanowski, that closed the Henri period. The exchange, up till the recent times called univocally a "duel," turns out to be, in the case of Adieu à la Pologne and Gallo crocitanti $\dot{\alpha} \mu o \imath \beta \dot{\eta}$ the start of a real, albeit ephemeral, dialogue beyond political and everyday reality, one at the level of art.

Key words: dialogue of cultures, Henry III of France, Desportes, Kochanowski, Ballet des Polonais, Antiquity in the Renaissance, $16^{\text {th }}$ century, Poland, France.

Translated by Marcin Turski

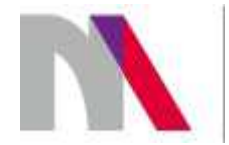

The preparation of the English version of Roczniki Humanistyczne (Annals of Arts) and its publication in electronic databases was financed under contract no. 836/P-DUN/2018 from the resources of the Minister of Science and Higher Education for the popularization of science. 